horizontal or ametropic meridian are not brought to a focus but overlap, and that consequently when the line looked at is horizontal, the overlapping being in the same direction as the line does not cause any blurring except at its two extremities. In such a case had the line looked at been vertica!, the effect produced would, of course, have been different, and the line blurred and indistinct from the rays overlapping on each side of it.

Anastigmagraph, illustrative and explanatory of theabove, was exhibited at the Birmingham meeting of the British Medical Association by Messrs. Curry and Paxton, of Great Portland street, W., and can be obtained from them. ${ }^{1}$

Harrogate.

\section{VOYAGING FOR HEALTH.}

ANOTHER CONTRIDUTION TO THE THERAPEUTICS OF THE SEA.

By ARTHUR I. MOSS, M.B., M.R.C.S., \&e.

HAVING read with very great pleasure the article by Mr. H. M. Doyle in THE LANCET of Aug. 2nd, and being thoroughly convinced of the importance of the subject, I venture to offer the result of my experience, which is, on the whole, less fortunate than that of Mr. Doyle.

During a period of eighteen months I travelled altogether over 50,000 miles at aea in almost every class of vessel, in rassenger sailing ship, in mail steamers, and in what are ealled "ocean tramps," and as a result of my own experience would utter a word of caution against the passenger sailing ship fur the invalid. If all of them came up to Mr. Doyle's description of the Sobraon and the route taken by her to the antipodes, my objections would mostly be without point, but unfortunately they seem a rare exception to the usual rule. In the first place, most sailing ships bound for the antipodes endeavour to make as fast a passage as possible, and to do so go much further sonth than apparently did the Sobroon, and return not by the Cape of Guod Hope, but round Cape Horn. As a result of this, strong westerly gales, bitterly cold weather, snow, ice, and rain are the usual climatic conditions to which tine invalid is subjected. For instance, I find from my log that on the seventy-fourth day of our outward voyage we were in latitude $49^{\circ} 39^{\prime} \mathrm{S}$, and in longitude $129^{\circ} 28^{\prime} \mathrm{E}$, and the weather was horribly cold, with rain and snow at in tervals, accompanied by a heavy gale from the north-west. For six weeks the same sort of weather prevailed, and with scarcely any intermissions. In latitude $42^{\circ} 56^{\prime} \mathrm{S}$. we met with ice, and for a week we saw numerous large icebergs. Our whole voyage from London to Port Lyttieton, New Zealand, lasted altogether ninetysix days, and out of that time we had eight weeks of disagreeably cold weather. We left London on Nov. 2.th, and had to lie at the Nore for five days because a south-west gale was blowing in the Channel. During those five days we had ample time to find out what sort of comfort we had to expect during cold weather. The ship had no stove in the saloon, and it seems to be the universal rule that none skould be provided i: sailing ships for New Zealand, because, as the owners tell you, it is a passage through u'arm weather. The consequence was that the skylights, ports, and every possible means of ventilation were kept carefully closed, the paraffin lamps were kept burning until some sort of warmth was obtained, while the passengers moped about in steaming overcoats in an atmosphere not far removed from that of a coal-mine after an explosion. The same sort of thing prevailed, though not quite so bad, while we were in the far southern latitudes. Another serious drawback from the comfort of most sailing ships is, that the quantity of fresh water available even for saloon passengers is decidedly limited. Indeed, it is sometimes very amusing to see the passengers flling their own water bottles from the carafes in the saloon. Surely this is not the sort of thing a medical man advises his phthisical patient to endure with any hope of cure. A very different state of aftairs from Mr. Doyle's account of "only ten days in eight months that the passengers were not able to enjoy themselves on deck." The unoral to be deduced from this for a phthisical patient is, Do not go in a sailing ship; or if you go, you must choose your

1 By the courtesy of the anthor a model of the astigmagraph has been submitted to us. - Ev. I. ship carefully and see that there is a stove in the saloon. I may remark that our ship was one of the best of one of the big companies carrying passengers to New Zealand.

The ship in which I came home was a steamer of nearly 5000 tons, with a splendid saloon, well warmed by steam, and thoroughly well ventilated. The main saloon and the best berths were all forward of the engine-room, so that there was no "smell of oil, and the rattle of the engines and the maddening revolution of the serew" were searcely perceptible. In fact, the difference between the misery of the sailing ship and the pleasant atmosphere of the steamer, even when rounding the Horn, was a change not readily to be forgotten. For a consumptive I should decidedly advise the voyage in a modern steamer, with the saloon forward of the engines.

I entirely agree with Mr. Doyle in his views as to the sort of consumptives who are likely to derive benefit from the voyage, and that none should be sent who had much nocturnal rise of temperature and sweating. Cases of slight tubercular consolidation and cases of pneumonic consolida. tion, not properly resolved, do well. The cases which are most benefited by a voyage in a sailing ship are decidedly those due to overwork, accompanied by physical weakness, anæmia, and dyspepsia. Sea-sickness in most cases seems to be almost a specific for the latter ailment. A dipsomaniac should never be sent to sea in a passenger ship, for the facilities of obtaining alcohol and the temptations of other passengers usually prove too strong for the patient. For such a case a voyage in a tramp steamer or ordinary eargo boat, where no liquor usually appears at table, is best. But the objection is that the food on board these boats, though usually good, is very plain.

With regard to the general uselessness of drugs in sea. sickness, I entirely agree with Mr. Doyle. I remember one case of an old lady who was badly sea-sick for seven weeks and had become fearfully emaciated; milk diet and some. what free doses of hyoscyamus seemed to have something to do with her recovery. Usually sea-sickness really begins when the patient attempts to get up and dress on the first morning at sea, and my advice, often successful, then is to stop quietly in bed until the patient has had some break. fast, then to have a little champagne, dress and go on deek, remaining there as long as possible. This plan I have known to be successful in preventing sea-sickness or lessening its terrors to several people who have been habitually sick every voyage.

On the question of outfit there is not very much to be said, but 1 should strongly advise everyone to take plenty of woollen clothing, but, above all, not to forget to include a good mackintosh, sea boots, and a sou'-wester hat. Thus prepared a passenger is often enabled to go on deck and stay there in comfort, when, if not so provided, he would either have to remain below or face an inevitable drenching on deck. Plans of the cabins of the varions ships ean usually be obtained from the owners, and should be attentively studied by every intending passenger. The principal points for guidance in the selection of a berth are--(1) size of state room and number of berths in it; (2) position not near w. c. or steward's pantry ; (3) as far forward as possible. In a sailing ship a berth on the port side is generally pre. ferred, but there is practically no real difference. These are the principal disadvantages, which have always to be reckoned with in every sea voyage, and if the attention of medical men is once drawn to them in a practical way, much disappointment and distress will be prevented, and greater benefit will be the result.

Penarth.

Miduand Counties Idotot Asylum. -The twentythird annual general meeting took place on the 13 th inst., at Malvern, Earl Beauchamp presiding. The report stated that the position of the asylum was satisfactory. Some of the patients had become exceedingly efficient and useful in domestic work. The total receipts had been $£ 1953$, and the expenditure £1524. During the year Mr. R. H. Foster of Knowle had succeeded Mr. G. W. Tait as nedical attendant; and the committee recorded their high appreciation of the valuable services rendered to the institution for fourteen years by Mr. Tait. Earl Beauchamp, in moving the adoption of the report and accounts, pointed out that so far from lunacy having increased, examination of statistics showed it to be now at its lowest ebb, and the improvement had been brought about by the great advance made in the medical treatment of the insane. 